\title{
Negotiating Ordinariness and Otherness: Superman, Clark Kent and the superhero masquerade
}

\author{
Barbara Brownie \\ Danny Graydon
}

\begin{abstract}
Superhero narratives are distinguished by the hero's negotiation of the relationship between two constructed identities, one ordinary, one extraordinary. The superhero, whose costume emphasizes otherness, shelters in the guise of a civilian, in a performance of ordinariness.

Prompted by Jacob Riis' invitation in 'How The Other Half Lives' (1890), journalists of that era engaged in performance of ordinariness in search of transstatus empathy. These journalists cloaked themselves in a 'signified cloth granting liberation and opportunity.' The clothes reduced their status, masking their profession or prestige, and they found themselves empowered. The disguises allowed them normalcy and anonymity, thereby enabling relationships and activities previously out of reach. Dressing down in civilian wardrobe, the superhero engages in similar trans-status disguise. By concealing otherness, he is liberated from the responsibilities of the superhero lifestyle and the extreme attention it garners.

Superman's civilian masquerade provides the freedom to engage with normal human society. We can consider his Clark Kent persona in terms of the trans-status observations emerging from social experiments that utilise disguise to enter a closed social group. Kal-El of Krypton is a 'covert operative' who originates from outside the subject of his study, and disguises himself in order to infiltrate the group. He learns their costumes and customs via his rural Kansas upbringing, and then in adulthood and the urban sprawl of Metropolis, positions himself as 'one of them.' Superman's relationship with his civilian alter-ego differs from that of other superheroes, who acquire their superpowers later in life. Spider-Man, for example, can be equated to a 'retrospective participant observer': he is able to model his civilian disguise on his own past experiences of ordinariness.

This paper will compare trans-status disguise in superhero comics to the activities of undercover journalists and social scientists, exploring the concealment of otherness through the performance of ordinariness.
\end{abstract}

Key Words: Superman, Clark Kent, secret identity, ordinariness, otherness, Jacob Riis, outsider, disguise, alter-ego, undercover. 


\section{Introduction}

Duality, and the struggle to negotiate the relationship between two different identities, helps to define the superhero genre. To balance the spectacle of the super identity, the superhero shelters in the guise of a civilian. The substitution of one of these identities for the other is a deliberate act of construction. The Kryptonian alien, Kal-El, has constructed two alternative identities for his life on Earth: the superhuman, Superman, and the journalist, Clark Kent. Each of these identities is a performance: one of otherness, and one of ordinariness. Numerous comics show the construction of the Superman identity: the design of the superman persona, and the donning of the costume for the first time. Likewise, we see the deliberate design of Clark Kent, and the constant maintenance of this performance of ordinariness. Parallels can be drawn to experiments by nineteenth century journalists, who dressed down in order to experience life among those less fortunate than themselves, and sociologists who act as covert operatives, infiltrating a social group to observe their culture and behaviours.

\section{Constructed Identities}

All superheroes have a complex relationship with identity. The superhero and the civilian alter-ego are two contrasting parts of a whole. Numerous texts have assumed one of these identities to be primary and genuine, and the other a disguise. Carl Jung saw Superman as 'the main personality' and Clark Kent as 'Superman's Shadow'. ${ }^{1}$ Superman can be considered the more genuine identity because it is the more alien. Since he was born Kal-El of the planet Krypton, the paranormal aspects of the Superman persona have been with him from birth, whereas he adopted his human identity later, after his adoption by Jonathan and Martha Kent.

However, few cultures believe that identity is fixed at birth. ${ }^{2}$ Identity is constructed over time. Clark Kent and Superman are both constructed identities, and both disguises. The character existed before both of his alter-egos came into being. For this character, the emergence of his two central identities occurs in adolescence or early adulthood. Until that point, there is only Clark Kent. He has had an apparently complete identity throughout his childhood, incorporating elements that we later attribute either to Kent or Superman. The boy, Clark Kent, performs feats of superhuman strength that would, later in life, be constrained to the Superman persona.

The details of Superman's masquerade were only lightly sketched in the opening decades of DC's Superhero publications. In is only in more recent narratives (particularly the post-1986 continuity) that writers have explored more fulsomely this aspect of the character. In these recent texts, the construction and maintenance of Kal-El's alternative personas is a collaborative act. In various origin stories, Martha and Jonathan Kent play key roles in the design of both 
personas, and later, other characters, including Lois, protect those identities by lying on his behalf. ${ }^{3}$

In Superman: Earth One, we see the deliberate construction of both personas, in collaboration with his adoptive parents. ${ }^{4}$ Martha Kent proposes to her son that he must construct an ordinary persona that will not attract attention or suspicion. This persona, she suggests, will be a 'mask' that conceals his extraordinary origins and abilities. He is later shown donning this 'mask' as he invents Clark Kent. In another recent version of Superman's origin, Superman: Birthright, Martha guides the construction of Clark's identity by cloaking him in a jacket and pushing glasses onto his nose. ${ }^{5}$

Superman: Secret Origin proposes that some elements of Clark's masquerade are designed to physically contain his superpowers. ${ }^{6}$ The Kent disguise restrains his powers, trapping him in a civilian persona. In this origin story, Clark's heat vision manifests when he is a teenager and he initially finds it impossible to control. Here, Marta Kent provides Clark with a pair of glasses made from Kryptonian crystals that travelled to Earth with Kal-El's ship. The crystal is able to absorb the heat vision, and thereby keep Clark's secret origins in check. Kal and his alien abilities are imprisoned within the props that will one day become central to Clark Kent's identity.

Rags Morales, the opening artist for the 2010 reboot of Action Comics (known as the 'New 52') describes drawing Clark Kent's wardrobes to conceal the superhuman otherness of his body: giving him baggy clothes to hide his muscles. ${ }^{7}$ Implicit in Morales' comments is the observation that Clark Kent is a performance; the entire identity is a construction.

In declaring that Clark Kent is the 'mask' (the alter-ego), it does not necessarily follow that the Superman identity is any less of a mask, or any more natural/genuine. All of these comics also show the construction of the Superman identity: they all show the donning of the costume for the first time, and Martha Kent's involvement in its design. Even though this character was born an alien, we cannot consider him to be innately 'Superman'.

At the moment when his two personas are constructed, Kal-El's identity is split into two. Clark Kent is refined and reduced to a mask of ordinariness, and Superman is created to contain the alien aspects of his identity. From this point onwards, the character exists in a perpetual state of incompleteness. The example of Superman shows that neither the Superman nor Clark Kent are a complete or genuine character. Both identities are constructions. Both are incomplete.

If neither Superman nor Clark are genuine or complete, it is difficult to define the character who unites these personas. Travis Langley's psychoanalysis of Batman proposes that superheroes are 'three-part' characters, consisting of the civilian 'façade', the superhuman, and the 'real man [or alien] behind both' ${ }^{8}$ KalEl is tripartite. He is Superman, Clark, and the hybrid that is responsible for both alter-egos. 
Arguably, this third character could be Kal-El. In Alan Moore's For The Man Who Has Everything, Superman's closest superhero confidantes refer to him as 'Kal', with the understanding that he is both and Superman and Clark, and yet neither. ' 'Kal', the character's Krytonian birth name, is used in acknowledgement of this third, hybrid identity: his only complete and true identity.

\section{Trans-status disguise and the performance of ordinariness}

Superman: Earth One (Vol. II) tells of how the young Clark Kent, an intellectually brilliant student, capable of outshining all his classmates, purposefully maintained a ' $\mathrm{C}$ ' grade for all his subjects. Lois Lane observes that Kent's academic performance was not only average, but consistently so. There was no subject at which he excelled, nor one at which he struggled. He maintained a precisely average level of interest and of academic achievement. ${ }^{10}$ Young Clark had repressed his extraordinary abilities, and constructed a persona that was modelled on the norm. He continues his performance of ordinariness into adulthood.

This kind of construction of ordinariness is core to experiments in 'trans-status disguise', ${ }^{11}$ a practice that flourished in the late nineteenth century social experiments, and is still vital in more recent journalistic practices such as those employed by Polly Toynbee. ${ }^{12}$ In 1890 , Jacob Riis published How The Other Half Lives, a taxonomy of class structure which included notes on 'bodily signifiers' of class, most notably, costume. In his text, Riis invited readers to covertly 'be with and among [the] people [of lower socioeconomic status] until you understand their ways' with the aim of encouraging greater trans-status empathy. ${ }^{13}$ There then began a trend for articles in British and American periodicals that featured the observations of 'middle-class [reporters] who briefly lived 'working-class' lives'. The accounts of these writers reveal dress as core in the construction of a transstatus disguise. In 1903, Jack London expressed surprise at how remarkably attitudes towards him changed when he donned a frayed jacket. The jacket, he noted, became a 'badge and advertisement of [his perceived] class'. By 'vesting [him]self in class-specific apparel' he invited observers to make assumptions about his socioeconomic status, and in so doing created opportunities to 'move freely' among social groups that had formerly viewed him as an outsider. ${ }^{14}$

These journalists and sociologists cloaked themselves in a 'signified cloth granting liberation and opportunity'. ${ }^{15}$ The clothes reduced their status, masking anything remarkable about their profession or prestige, and they found themselves empowered. The disguises gave them a peculiar power of normalcy and anonymity, which allowed them to partake in relationships and activity that were previously out of their reach. As Kent, Kal experiences this same liberation. In his civilian clothes he is able to walk down the street, sleep in an ordinary bed, shop for groceries, and form relationships. Perhaps most importantly, he is able to drop 
his guard. The civilian clothing provides relief from the constant pressure to save the day, and to live up to his own remarkable reputation.

Kent's glasses are the cornerstone of his disguise. They are a kind of 'costume shorthand, ${ }^{16}$ that provide the pivotal event in the transition from one alter-ego to the other, regardless of what else he is wearing, the glasses are enough to mark Kent apart from Superman. Glasses are markers of a physical flaw, apparently reducing Kal-El to a lesser-being and connecting him to humanity. In Kingdom Come, Kal-El is the dominant persona, with Superman and Clark Kent having been wilfully abandoned in mourning for Lois Lane. The glasses are the object that recalls him to the human world. Having thought his humanity lost, he pushes the glasses onto his face, and suddenly he is Clark again. ${ }^{17}$

It is notable that Kal-El's civilian persona is also a journalist. Like few other professions, this grants him access to the human race, and provides him with opportunities to observe human behaviour in great detail and in all walks of life. It allows his to observe ordinariness, and learn from it.

\section{Clark Kent the 'Covert Operative'}

Superman does not naturally fall into this mould of ordinariness. Kal-El must make a conscious effort to conceal his otherness. In Camelot Falls we see Clark Kent as a passenger on a commercial airliner. ${ }^{18}$ In his balloon dialogue he converses with the cabin attendant as Clark, meanwhile, narrative boxes reveal his inner monologue as Superman. His conversation with the attendant is mundane. They discuss the seatbelt sign, and the effect that the turbulence may be having on Clark's stomach. Meanwhile, his inner thoughts reveal plans to exit the craft via the landing gear doors, allowing the transformation into Superman to attend to an alien threat below. Kal has learnt from observation that this is an appropriate way for humans to behave. He is not genuinely troubled by the turbulence, but he has observed this behaviour in the humans around him, and mimicked it. The entire Clark Kent persona has been constructed in the same way - through observation of the human race.

For Kal-El, the clothes of his civilian persona are not merely 'ordinary'; they are a very specific interpretation of 'ordinary'. This is 'ordinary' from the perspective of the superhero; 'ordinary' viewed through the eyes of the extraordinary. Clark Kent is Kal's 'opinion of the rest of us' and his everyday workwear is [his] interpretation of how the normal, human population dress. Clark Kent is 'a painted caricature' of what Kal sees as an average human male. ${ }^{19}$ Kent's civilian clothing therefore offer insight into how he views humanity - at least in its most typical, American form - dull and stiff.

This 'covert operative' approach to the alter-ego sets Superman apart from other superheroes. While Superman learns from observation, Batman and Spider Man learn from recollection. Superheroes who have acquired their powers later in life have a previous self as a model for their civilian persona. Spider Man did not 
have to invent his civilian wardrobe the way he did his Spider Man costume; he only has to maintain it. Likewise, Bruce Wayne had wardrobes full of expensive suits before he built his Batman costumes. But even in these cases, as soon as they don the superhero suit, the civilian wardrobe becomes part of a disguise, and the hero must be conscious of the persona that it communicates. They must try to dress and behave as they did before they acquired their superhero identity. They must preserve the image of their former selves.

Comparisons can be made to the methods used by undercover researchers. There are 'strict codes of cultural boundaries which are vigorously enforced' necessitate the invention of false identities. ${ }^{20}$ Secret identities are constructed in order to 'gain research access to otherwise closed research settings'. This may occur when the subject of a study is 'closed or inaccessible' to outsiders, just as normal human society is likely unwilling to accept a super-powered semi-human as one of their own. Humanity is a closed society; we do not treat non-humans (or those with non-human powers) as equals, and so it would be difficult for a superhero to lead any semblance of a normal life, or to integrate into society, were he not disguised as ordinary.

Likewise, a journalist who intends to write an article on the Mafia, a spy who intends to investigate a terrorist cell, or an anthropologist who intends to analyse aspects of sub-culture, must present themselves with an identity that is 'indigenous to that setting'. Covert participant observation, when it is employed in journalistic, anthropological or other social studies, falls into several categories. Martin Blumer identifies two of the roles these covert researchers play as 'covert outsider' and 'retrospective participant observer'. ${ }^{21}$ The 'covert outsider' is one who originates from outside the subject of his study, and disguises himself in order to infiltrate the group. He learns their costumes and customs, and then positions himself as 'one of them'. His real identity remains secret. Superman falls into this category. As Kal$\mathrm{El}$, he is 'the last son of Krypton', an outsider to human society. He uses his childhood experiences to construct a believable pastiche of an ordinary human, and adopts that identity in passing himself off as the human Clark Kent. Other superheroes, who have acquired their powers later in life (Batman, Spider Man, etc.), are 'retrospective participant observers', having participated in ordinary human society before they became super-powered. Throughout this learning process, they were genuine participants in civilian society. They are able to reflect on their past experiences, and use them to create a model on which they construct their civilian disguise.

\section{Conclusion}

The Clark Kent masquerade appears so ordinary that it does not overtly present itself as a costume or disguise. It is that ordinariness that places him beyond suspicion. In The Secret Revealed, Lex Luthor deploys his vast technological resources to discover Superman's true identity. ${ }^{22}$ When the lead investigator 
presents Luthor with the computer's simple conclusion, that 'Clark Kent Is Superman', Luthor refuses to believe it. Kent is seemingly so removed from the hyper-masculine Superman that any similarities are overlooked. The behaviour of $\mathrm{Kal}-\mathrm{El}$, in constructing his alternative personas, is not exclusive to comic book fiction. There are parallels with the actions of real-life journalists, anthropologists and sociologists, who perform new identities to infiltrate closed social groups.

\section{Notes}

${ }^{1}$ Jung, Karl, Man and his Symbols, New York: Doubleday, 1964, as cited in Langley, Travis, Batman and Psychology, Hoboken, New Jersey: John Wiley \& Sons, 2012, p. 171.

${ }^{2}$ See, for example, Barker, Chris, Cultural Studies Theory and Practice, $2^{\text {nd }}$ ed. Oxford: The Alden Press, 2003, p. 231.

${ }^{3}$ See, for example, Busiek, Kurt, Superman: Camelot Falls, New York: DC Comics, 2007.

${ }^{4}$ Straczynski, J. Michael, and Davis, Shane, Superman: Earth One, Vol. 2, New York: DC Comics, 2012.

${ }^{5}$ Waid, Mark, Superman: Birthright, New York, DC Comics, 2004, p. 84.

${ }^{6}$ Johns, Geoff, Superman: Secret Origin, New York: DC Comics, 2010.

${ }^{7}$ Morales, Rags, as cited in Morison, Grant, and Morales, Raggs, Action Comics: Superman and the Men of Steel, Vol. 1, The New 52, New York: DC Comics, 2012.

${ }^{8}$ Langley, Travis, Batman and Psychology, Hoboken, New Jersey: John Wiley \& Sons, p. 160.

${ }^{9}$ Moore, Alan, Across the Universe: The DC Universe Stories of Alan Moore, New York: DC Comics, 2003.

${ }^{10}$ Straczynski, J. Michael, and Davis, Shane, Superman: Earth One, Vol. 2, New York: DC Comics, 2012, p. 4

${ }^{11}$ Hyland, Peter, 'The Performance of Disguise', Early Theatre, Vol. 5, No. 1 (2002), pp. 77-83.

${ }^{12}$ See Toynbee, Polly, Hard Work: Life in Low-pay Britain, London: Bloomsbury, 2003, a record of the experiences of journalist, Toynbee, who spends a period living and working on minimum wage in order to expose the difficulties encountered by those of lower socioeconomic status than herself and her readers.

${ }^{13}$ Schocket, Eric, 'Undercover Explorations of the "Other Half," or the Writer as Class Transvestite,' Representations, No. 64 (1998), pp. 109-133, 112, 118.

${ }^{14}$ London, Jack, People of the Abyss, 1903, cited in Schocket, Eric, 'Explorations of the 'Other Half,' or the Writer as Class Transvestite,' Representations 64 (1998), p. 119.

${ }^{15}$ Fhlainn, Sorcha Ni, 'Our Monstrous (S)kin: Blurring the Boundaries Between Monsters and Humanity', in Our Monstrous (S)kin, ed. Fhlainn, Sorcha Ni, Oxford: Interdisciplinary Press, 2009, p. 9.

${ }^{16}$ Hyland, Peter, 'The Performance of Disguise', Early Theatre, Vol. 5, No. 1 (2002), pp. 77-83, 81 .

${ }^{17}$ Waid, Mark, Kingdom Come, New York: DC Comics, 1997, pp. 200-201.

${ }^{18}$ Busiek, Kurt, Superman: Camelot Falls, New York: DC comics, 2007. 
${ }^{19}$ Jules Feiffer, as cited in De Haven, Tom, Our Hero: Superman on Earth, London: Yale University Press, 2010, p. 38.

${ }^{20}$ Fhlainn, Sorcha Ni, 'Our Monstrous (S)kin: Blurring the Boundaries Between Monsters and Humanity', in Our Monstrous (S)kin, ed. Fhlainn, Sorcha Ni, Oxford: Interdisciplinary Press, 2009, p. 4.

${ }^{21}$ Blumer, Martin, 'When is Disguise Justified? Alternatives to Covert Participant Observation', Qualitative Sociology, Vol. 5, No. 4, pp. 251-264.

22 Byrne, John, Superman: The Secret Revealed, New York: DC Comics, 1986, p.21-22.

\section{Bibliography}

Barker, Chris. Cultural Studies Theory and Practice. $2^{\text {nd }}$ ed. Oxford: The Alden Press, 2003.

Blumer, Martin. 'When is disguise justified? Alternatives to covert participant observation.' Qualitative Sociology, Vol. 5, No. 4 (1982), 251-264

Busiek, Kurt. Superman: Camelot Falls. New York: DC Comics, 2007.

Collins, Lucy. 'Fashion as Confession: Revelation and Concealment in Personal Identity.' Paper presented at Fashion: Exploring Critical Issues, Mansfield College, Oxford, 23-25 September, 2011.

Hyland, Peter, 'The Performance of Disguise', Early Theatre, Vol. 5, No. 1 (2002), Johns, Geoff. Superman: Secret Origin. New York: DC Comics, 2010.

Karaminas, Vicki, 'Übermen: Masculinity, Costume, and Meaning in Comic Book Superheroes.' In The Men's Fashion Reader, edited by Vicki Karaminas, 179-186. Oxford: Berg, 2009.

Langley, Travis. Batman and Psychology. Hoboken, New Jersey: John Wiley \& Sons, 2012.

Moore, Alan. Across the Universe: The DC Universe Stories of Alan Moore. New York: DC Comics, 2003.

Morison, Grant, and Morales, Raggs. Action Comics: Superman and the Men of Steel, The New 52: Vol. 1. New York: DC Comics, 2012.

Morris, Tom. 'What's Behind the Mask? The Secret of Secret Identities.' In Superheroes and Philosophy, edited by Tom Morris and Matt Morris, 25-267. Illinois: Carus, 2005.

Reynolds, Richard. Super Heroes: A Modern Mythology. London: Batsford, 1992. 
Schocket, Eric. 'Undercover Explorations of the "Other Half," or the Writer as Class Transvestite.' Representations, No. 64 (1998), 109-133.

Fhlainn, Sorcha Ni, 'Our Monstrous (S)kin: Blurring the Boundaries Between Monsters and Humanity', in Our Monstrous (S)kin, ed. Fhlainn, Sorcha Ni, Oxford: Interdisciplinary Press, 2009.

Straczynski, J. Michael, and Davis, Shane. Superman: Earth One, Vol. 2, New York: DC Comics, 2012.

Toynbee, Polly. Hard Work: Life in Low-pay Britain. London: Bloomsbury, 2003.

Waid, Mark. Kingdom Come. New York: DC Comics, 1997.

Waid, Mark. Superman: Birthright. New York, DC Comics, 2004.

Barbara Brownie leads online postgraduate study in the School of Creative Arts at the University of Hertfordshire. She also writes for The Guardian on Costume and Culture. Her current research interests include film costume, trans-status disguise, and clothes as objects.

Danny Graydon is a UK-based critic, author and academic specialising in Film and Comics. A long-time contributor to EMPIRE Magazine, he lectures at University of Hertfordshire and Kingston University, London and is the author of five books relating to cinema. 